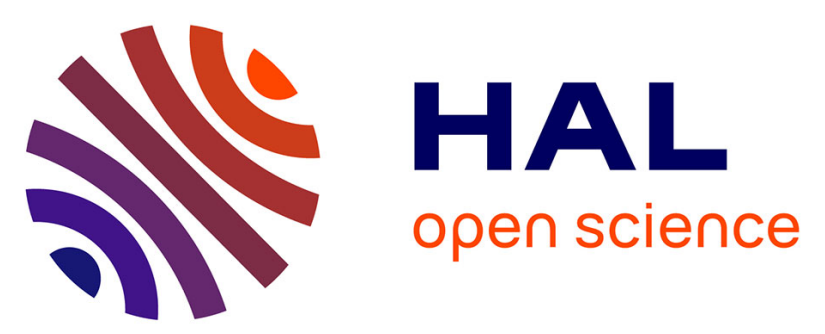

\title{
Formation and stability of CoMoS nanoclusters by the addition of citric acid: A study by high resolution STEM-HAADF microscopy
}

Luz Zavala-Sanchez, Xavier Portier, Françoise Maugé, Laetitia Oliviero

\section{- To cite this version:}

Luz Zavala-Sanchez, Xavier Portier, Françoise Maugé, Laetitia Oliviero. Formation and stability of CoMoS nanoclusters by the addition of citric acid: A study by high resolution STEM-HAADF microscopy. Catalysis Today, 2021, Catalysis by Sulfides and related materials, 10.1016/j.cattod.2020.10.039 . hal-03025108

\section{HAL Id: hal-03025108}

https://hal-normandie-univ.archives-ouvertes.fr/hal-03025108

Submitted on 21 Dec 2020

HAL is a multi-disciplinary open access archive for the deposit and dissemination of scientific research documents, whether they are published or not. The documents may come from teaching and research institutions in France or abroad, or from public or private research centers.
L'archive ouverte pluridisciplinaire $\mathbf{H A L}$, est destinée au dépôt et à la diffusion de documents scientifiques de niveau recherche, publiés ou non, émanant des établissements d'enseignement et de recherche français ou étrangers, des laboratoires publics ou privés. 
Formation and stability of CoMoS nanoclusters by the addition of

Citric Acid: a study by High resolution STEM-HAADF microscopy.

Luz Zavala-Sanchez ${ }^{1}$, Xavier Portier ${ }^{2}$, Françoise Maugé ${ }^{1}$, and Laetitia Oliviero ${ }^{1}$

${ }^{1}$ Normandie Univ, ENSICAEN, UNICAEN, CNRS, LCS, 14000 Caen, France.

${ }^{2}$ Centre de recherche sur les lons, les Matériaux et la Photonique, CEA, UMR CNRS 6252, Normandie Université, ENSICAEN, UNICAEN, CNRS, 6, bd du Maréchal Juin, 14050 Caen, France.

\section{E-mail: laetitia.oliviero@ensicaen.fr}

\section{ABSTRACT}

In this work, we present atomic-scale images of Co promoted $\mathrm{MoS}_{2}$ slabs supported on $\mathrm{y}-\mathrm{Al}_{2} \mathrm{O}_{3}$ obtained by High Resolution Scanning Transmission Electron Microscopy equipped with High Angular Annular Dark Field detector (HR STEM-HAADF). These images allow to study the effect of citric acid (CA) addition during preparation, on the slab length and its stability during thiophene hydrodesulfurization (HDS) reaction. Thus, the observations, obtained for sulfide catalysts prepared without or with citric acid as chelating agent, evidenced strong decrease in size of the CoMoS nano-slabs as detected indirectly by the adsorption of CO followed by Infrared spectroscopy (IR/CO). Quantitative dispersion values were calculated from the images taking into account the true shape of the particles instead of the classical hexagonal shape 
hypothesis. Characterization of the used catalyst shows that these nanoclusters are stable under model thiophene HDS reaction.. Such observations allow a better understanding of the effect of chelating agent addition on promoted $\mathrm{MoS}_{2}$ samples in order to explain their catalytic activity.

KEYWORDS: HR STEM-HAADF, CoMoS, Citric acid, CO adsorption, IR spectroscopy, Sulfide nanoparticles morphology, , used catalyst.

Graphical Abstract:
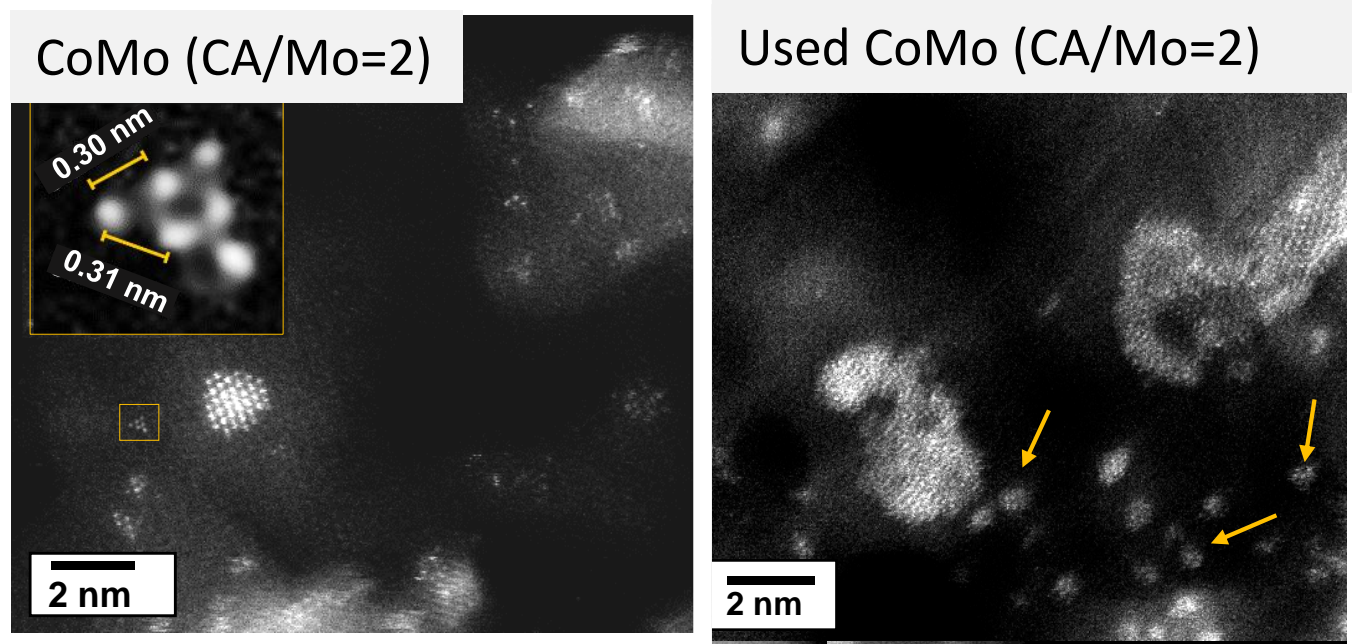

\section{Introduction}

The increasing demand for low sulfur fuels puts pressure on the development of more active catalysts for the production of clean transportation fuels. However, 
current oil deposits have higher sulfur concentration [1] and, strict fuel regulations are being established in both developed and developing countries [2]. To meet environmental standards, the oil industry is producing ultra-low sulfur diesel fuel (ULSD), a cleaner fuel containing a maximum of 10 parts per million (ppm) of sulfur. This level is likely to be further decreased by environmental legislation in subsequent years. Hydrodesulfurization (HDS) catalysts are mainly based on supported transition-metal disulfides (TMS) [3]. The TMS active phase is usually composed of molybdenum (Mo) or tungsten (W), promoted by cobalt (Co) or nickel (Ni). Although the non-promoted $\mathrm{MoS}_{2}\left(\mathrm{WS}_{2}\right)$ catalysts do not present high catalytic activity, a very significant increase in activity can be achieved by adding $\mathrm{Co}$ or $\mathrm{Ni}[4,5]$. Then a bimetallic sulfide phase is formed, typically called the CoMoS, NiMoS, or NiWS phase, whose structure corresponds to a two-dimensional (2D) nanolayer of $\mathrm{Mo}(\mathrm{W}) \mathrm{S}_{2}$ decorated by the promoter at its edges, as described in the so-called CoMoS model [4-7]. The sulfide phase presents a lamellar structure, formed by layers of $\mathrm{MS}_{2}(\mathrm{M}=\mathrm{W}, \mathrm{Mo})$. These particles are often supported on high specific surface area carriers such as $\mathrm{Y}$-alumina $\left(\mathrm{y}-\mathrm{Al}_{2} \mathrm{O}_{3}\right)$. Co-promoted $\mathrm{MoS}_{2}$ nanostructured catalysts are traditionally used for hydrotreatment reactions. CoMo catalysts are some of the most used catalyst for reaching ULSD levels. They have been the subject of research in numerous studies to determine their structure and to identify their active sites [8-10]. Active sites in sulfided CoMoS catalysts are associated to the nano-slabs exposed edges, i.e. M-edge and S-edge. Lowtemperature $\mathrm{CO}$ adsorption followed by infrared spectroscopy $(\mathrm{IR} / \mathrm{CO})$ is a technique that gives access to the site dispersion and then to their intrinsic activity. It has been intensively used to probe the edges sites of $\mathrm{MoS}_{2}$ slabs on $\mathrm{MoS}_{2} / \mathrm{Al}_{2} \mathrm{O}_{3}$ catalysts. 
Previous results of our group [11-13], have demonstrated that the S-edge is more active than the M-edge in thiophene HDS reaction and is also more favored in being promoted, therefore, the increase of S-edge/M-edge ratio leads to an increase of HDS activity. In this way, CoMoS slabs morphology can be expected to be related to the catalytic activity. The concentration of S- and M-edge sites and the distinction of the promoted sites is essential to accurately explain their activity and their selectivity. In addition, parameters of preparation of these catalysts as effect of support, conditions for the preparation of the initial oxide phase, sulfidation conditions among others, play an important role in the final result in catalytic performance.

Recent advances in high-resolution scanning transmission electron microscopy (HR STEM) imaging have opened up the possibility of studying two-dimensional materials with atomic-level resolution and sensitivity. In addition to conventional TEM-based modes, a very useful alternative to characterize materials at a subnanometer scale is HR STEM-HAADF. In this STEM mode, the annular detector collects high angle scattered electrons and the intensity of the image depends on the atomic number within the sample and is approximately proportional to $Z{ }^{1.7}$ $[14,15]$. Due to its high sensitivity to heavy metal atoms (such as Mo, W and even Co and $\mathrm{Ni}$ ), a -STEM-HAADF analysis is the best alternative to evaluate parameters such as slab shape and structural characteristics.

Improving the dispersion degree of active metals is another crucial idea to enhance the activity of sulfided catalysts. Various methods have been developed to prepare well-dispersed catalysts. The addition of chelating agents have a special and efficient role in increasing the dispersion degree of $\mathrm{Co}(\mathrm{Ni})-\mathrm{Mo}-\mathrm{S}$ active phases 
[16-18] by interacting with the precursor ions and the support surface. However, the effect of the addition of citric acid in the preparation of promoted catalysts is always somewhat controversial since both increase [19] and decrease [20] in dispersion have been reported. Moreover, while in the non-promoted catalysts the variation of morphology with the addition of citric acid was indirectly observed by IR/CO method,

that is, the S-edge/M-edge ratio was closer to one after CA addition, for the promoted systems this is still inconclusive. In particular, a better distinction of the nature of the promoted sites by IR/CO is required. But, the results of catalytic activity, as well as those of IR spectroscopy obtained from non-promoted and promoted samples, have certain consistency: citric acid addition provokes a considerable increase in catalytic activity and in total site concentration.

In this work, the aim is to observe by direct image characterization the slab morphology of sulfided $\mathrm{Al}_{2} \mathrm{O}_{3}$ supported CoMo catalysts prepared at the same conditions of synthesis and sulfidation that the ones for the catalytic application. Then a parallel study of the effect of citric acid by means of HR STEM-HAADF and IR/CO spectroscopy method is carried out. Finally, the effect of using the CoMo catalyst prepared with CA in model thiophene HDS reaction is studied to check the stability of the observed slabs.

\section{Experimental}

\subsection{Catalyst preparation}

$\mathrm{CoMo} / \mathrm{Al}_{2} \mathrm{O}_{3}$ catalysts, without and with citric acid $(\mathrm{CA})$, were prepared by a one-step pore volume impregnation method. The aqueous impregnation solutions were 
prepared by dissolving a fixed amount of ammonium heptamolybdate tetrahydrate $\left(\left(\mathrm{NH}_{4}\right)_{6} \mathrm{Mo}_{7} \mathrm{O}_{24} \cdot 4 \mathrm{H}_{2} \mathrm{O} \mathrm{MERCK}\right)$ and cobalt (II) nitrate hexahydrate $\left(\mathrm{Co}\left(\mathrm{NO}_{3}\right)_{2} \cdot 6 \mathrm{H}_{2} \mathrm{O}\right.$ Alfa Aesar) in deionized water at room temperature. Citric Acid (CA) was incorporated at this stage by dissolving the required amount $\left(\mathrm{C}_{6} \mathrm{H}_{8} \mathrm{O}_{7} \cdot \mathrm{H}_{2} \mathrm{O}\right.$ PROLABO) to obtain a $\mathrm{CA} /(\mathrm{M})=0$ or $2,(\mathrm{M}=\mathrm{Mo}+\mathrm{Co})$. Afterwards, the solution was added to the pretreated $\mathrm{y}-\mathrm{Al}_{2} \mathrm{O}_{3}$ support (SASOL, specific surface area of $252 \mathrm{~m}^{2} \cdot \mathrm{g}^{-}$ ${ }^{1}$ and pore volume of $0.84 \mathrm{~mL} \cdot \mathrm{g}^{-1}$, precalcined in air at $723 \mathrm{~K}$ for $2 \mathrm{~h}$ ), strongly shaken and left for maturation during $2 \mathrm{~h}$. Finally, the catalysts were dried at $383 \mathrm{~K}$ for $16 \mathrm{~h}$. Note that these catalysts were not calcined in order to keep the chelating agent if present in its initial form. Hereinafter, the $\mathrm{CoMo} / \mathrm{Al}_{2} \mathrm{O}_{3}$ catalysts are denoted CoMo $(C A / M=x) / \mathrm{Al}_{2} \mathrm{O}_{3} . \mathrm{X}$ refers to the molar ratio of $\mathrm{CA}$ to $\mathrm{Mo} ; \mathrm{x}=0$ or 2.0. For these two $\mathrm{CoMo}(\mathrm{CA} / \mathrm{M}=\mathrm{x}) / \mathrm{Al}_{2} \mathrm{O}_{3}$ catalysts, the content of Mo was fixed to $3.2 \mathrm{Mo}$ atoms per $\mathrm{nm}^{2}$, and the $\mathrm{Co} /(\mathrm{Co}+\mathrm{Mo})$ ratio was equal to 0.3 .

The $\mathrm{CoMo}(\mathrm{CA} / \mathrm{M}=2) / \mathrm{Al}_{2} \mathrm{O}_{3}$ catalysts was then tested in thiophene hydrodesulfurization (HDS) reaction. A mass of $50 \mathrm{mg}$ of catalyst (20-40 meshes, precisely weighed) was first sulfided with $30 \mathrm{~mL} \cdot \mathrm{min}^{-1} 10 \%(\mathrm{v} / \mathrm{v}) \mathrm{H}_{2} \mathrm{~S} / \mathrm{H}_{2}$ at $623 \mathrm{~K}(3$ $\mathrm{K} \cdot \mathrm{min}^{-1}$ ) for $2 \mathrm{~h}$. Then, the catalytic activity of thiophene HDS was tested at $623 \mathrm{~K}$ using a $90 \mathrm{~mL} \cdot \mathrm{min}^{-1}$ gas mixture consisting of $7.9 \%$ thiophene, $90.0 \% \mathrm{H}_{2}$, and $2.1 \%$ $\mathrm{H}_{2} \mathrm{~S}$. The sample was left under these conditions during $72 \mathrm{~h}$.

\subsection{Low-Temperature CO Adsorption Followed by IR Characterization (IR/CO).}

The CoMos edge sites of these catalysts were in-situ characterized by lowtemperature CO adsorption followed by IR spectroscopy $[12,19,21,22]$. First, the dried catalytic precursor in oxidic form was grounded and pressed into a self- 
supported wafer $\left(10 \mathrm{mg}\right.$ for a disc of $2.01 \mathrm{~cm}^{2}$ ) precisely weighted and positioned into a quartz IR cell with $\mathrm{CaF}_{2}$ windows. Then, the catalyst pellet was sulfided at 623 $\mathrm{K}\left(3 \mathrm{~K} \cdot \mathrm{min}^{-1}\right)$ at atmospheric pressure under $30 \mathrm{~mL} \cdot \mathrm{min}^{-1} 10 \% \mathrm{H}_{2} \mathrm{~S} / \mathrm{H}_{2}$ for $2 \mathrm{~h}$. After that, the reactor was flushed by Ar for $10 \mathrm{~min}$ and evacuated during $1 \mathrm{~h}$ at $623 \mathrm{~K}$. Finally, after being cooling down to room temperature, the sulfided pellet was transferred to the IR optical path. Prior to the adsorption experiments, the sample was sulfided in situ in the IR cell. For this, the catalysts was sulfided in a gas mixture containing $10 \% \mathrm{H}_{2} \mathrm{~S} / \mathrm{H}_{2}\left(30 \mathrm{~mL}^{\cdot} \mathrm{min}^{-1}\right)$ at $623 \mathrm{~K}$ for two hours with a heating rate of 3 $\mathrm{K} \cdot \mathrm{min}^{-1}$. After sulfidation, the cell was flushed with $\mathrm{Ar}$ and evacuated up to $\mathrm{P}<1 \cdot 10^{-4}$ Pa until the catalyst reached room temperature. Then, $\mathrm{CO}$ adsorption was performed at low temperature $(\sim 100 \mathrm{~K})$ to avoid any reaction with the catalysts surface. Small calibrated doses of $\mathrm{CO}$ were introduced into the IR cell until equilibrium pressure of $133 \mathrm{~Pa}$. After each CO introduction, FTIR spectra were recorded with 256 scans and a resolution of $4 \mathrm{~cm}^{-1}$ using Nicolet Nexus FT-IR spectrometer equipped with a MCT Detector.

\subsection{HRTEM and High-resolution Scanning Transmission Electron Microscopy - High} Angular Annular Dark Field (HR STEM-HAADF).

All presented TEM images were taken using a double corrected JEOL ARM 200F cold FEG microscope operated at $200 \mathrm{kV}$. First, slab length and stacking degree distributions of sulfide slabs were determined manually by measuring around 300 slabs per sample from HRTEM images. The image treatment was performed using the commercial software from GATAN (DIGITALMICROGRAPH). The nanostructure and morphology of the $\mathrm{MoS}_{2}$ slabs were analyzed by high resolution scanning 
transmission electron microscopy (HR STEM) using a high angle annular dark field (HAADF) detector. The catalyst precursors were firstly sulfided at $623 \mathrm{~K}$ (heating rate of $3 \mathrm{~K} \cdot \mathrm{min}^{-1}$ ) and $0.1 \mathrm{MPa}$ for $2 \mathrm{~h}$ under a $30 \mathrm{~mL} \cdot \mathrm{min}^{-1}$ flow of $10 \% \mathrm{H}_{2} \mathrm{~S} / \mathrm{H}_{2}$. Then, to limit detrimental exposure to air, the sulfided catalysts were unloaded from the sulfidation reactor under argon flow and deposited into absolute ethanol. A few drops of the suspension of catalyst were put on a 300 mesh copper grid with holey carbon film. The STEM images presented in this manuscript were obtained in HAADF mode and the acquisition of an image lasted about $30 \mathrm{~s}$ with a resolution of 1024 pixels $\mathrm{x}$ 1024 pixels, ( $30 \mu \mathrm{s}$ of exposure time for each spot in the scanning mode). The possible damage associated with the heating effects caused by the incident beam in the nanolayers is always a factor to consider. In this study, it was not observed significant changes during the acquisition of the images at $200 \mathrm{kV}$ with a beam current value of about $12 \mu \mathrm{A}$. Observations at $80 \mathrm{kV}$ were also performed, but no significant differences in terms of slab stability were noticed. Therefore, it was concluded that the operation with an acceleration of $200 \mathrm{kV}$ is compatible with our purpose of morphological analysis.

Following an approach similar to that of our recent work [20], a set of 20 individual nanoparticles (observed on HAADF mode) of samples $\mathrm{CoMo}(\mathrm{CA} / \mathrm{M}=0) / \mathrm{Al}_{2} \mathrm{O}_{3}, \quad \mathrm{CoMo}(\mathrm{CA} / \mathrm{M}=2) / \mathrm{Al}_{2} \mathrm{O}_{3}$ and $\mathrm{CoMo}(\mathrm{CA} / \mathrm{M}=2) / \mathrm{Al}_{2} \mathrm{O}_{3}$ after catalytic reaction (used catalyst), was taken through contrast optimization of the images. This in order to obtain statistical information about the morphology of the Co promoted $\mathrm{MoS}_{2}$ slabs. In these individual nanoparticles, the outline of the shape was drawn and the corresponding particle lengths were measured, as well as the area of the particle with the help of the Mesurim Pro software. The limited number of particles 
analyzed by STEM-HAADF compared to HRTEM is explained by the difficulty to observe isolated specimens with faceted edges in these realistic samples. This is associated to the high metal loading present in this type of catalysts. Considering that for each slab, the dispersion is the ratio of edge atoms per total atoms, the calculated dispersion (D) values were obtained through the measurement of slab area and perimeter with the following equation (1):

$$
D=\frac{\text { atoms at the edge }}{\text { total number of atoms per slab }}=\frac{P / d^{-N_{C}}}{A / d^{2}}
$$

Where:

$\mathrm{D}=$ dispersion

$\mathrm{P}=$ particle perimeter $(\mathrm{nm})$

$\mathrm{d}=$ atomic diameter Mo $(\mathrm{nm})$

$\mathrm{Nc}=$ number of corner atoms in the slab

$A=$ particle area $\left(\mathrm{nm}^{2}\right)$

Calculating a numeric value of dispersion will more directly reflect the effect of citric acid in the morphology of the studied catalysts than simple observation.

\section{Results and discussion}

\subsection{IR/CO Characterizations of Sulfided $\mathrm{CoMo}(\mathrm{CA} / \mathrm{M}=0$ and 2$) / \mathrm{Al}_{2} \mathrm{O}_{3}$ Catalysts.}

Low-temperature (liquid nitrogen temperature) CO adsorption followed by in situ IR spectroscopy (IR/CO) allows distinguishing non-promoted $\left(\mathrm{MoS}_{2}\right)$ sites and promoted (CoMoS) sites $[19,23,24]$ on the supported CoMo catalyst. Figure 1 reports the IR/CO spectra obtained on the $\mathrm{CoMo}(\mathrm{CA} / \mathrm{M}=\mathrm{x}) / \mathrm{Al}_{2} \mathrm{O}_{3}$ catalysts. The two bands located around 2189 and $2156 \mathrm{~cm}^{-1}$ are ascribed respectively to CO interaction with Lewis acid sites and hydroxyl groups of the $\mathrm{Al}_{2} \mathrm{O}_{3}$ support. 
The strong band at around $2072 \mathrm{~cm}^{-1}$ is attributed to the CO adsorption on Copromoted $\mathrm{MoS}_{2}$ edges (the so-called CoMoS sites), while the small shoulder at 2115 $\mathrm{cm}^{-1}$ is attributed to $\mathrm{CO}$ adsorption on unpromoted $\mathrm{MoS}_{2}$ sites $[13,19]$. In addition in CoMo $(\mathrm{CA} / \mathrm{M}=2) / \mathrm{Al}_{2} \mathrm{O}_{3}$ sample, a second band in the promoted massive is observed at $2060 \mathrm{~cm}^{-1}$, assigned by Dominguez et al. [25] to partially promoted S-edge.

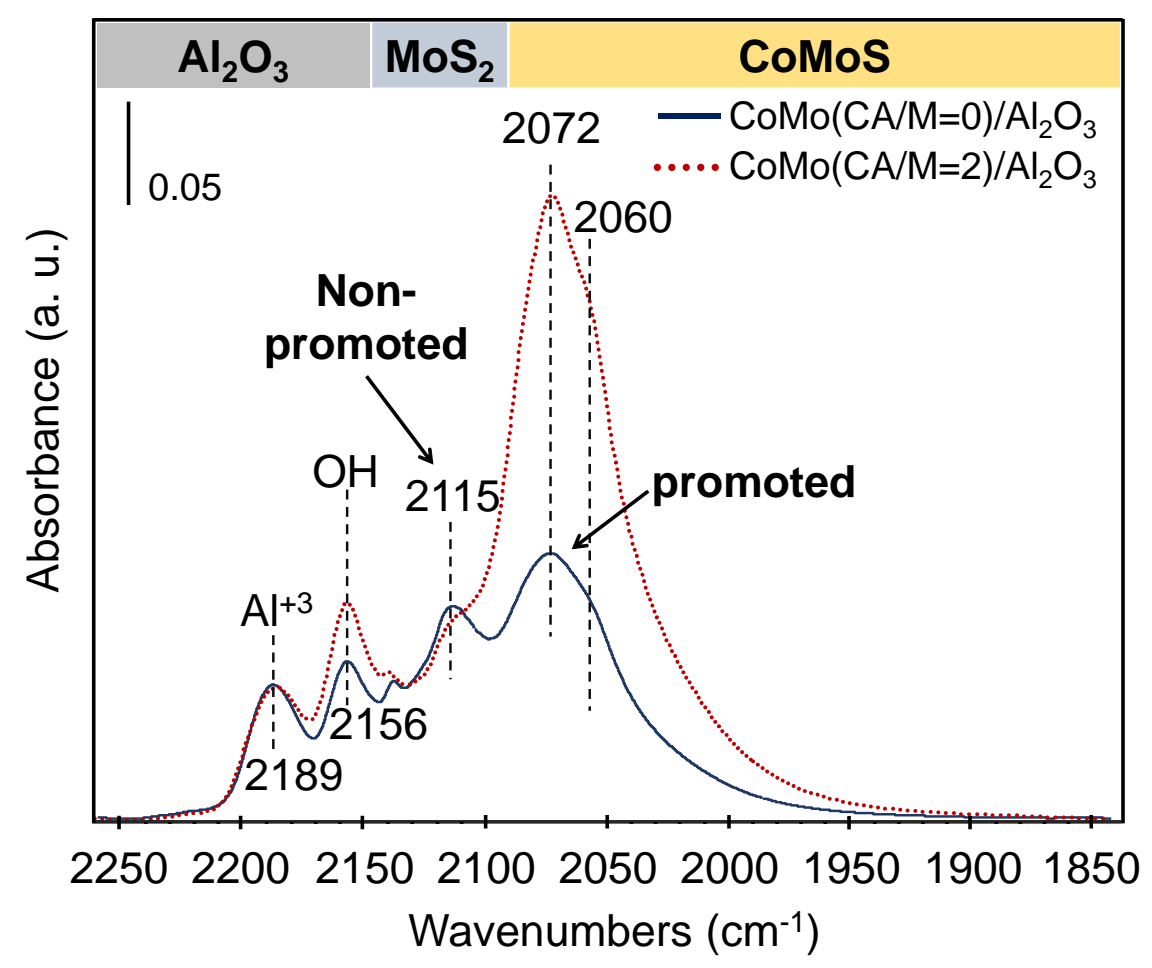

Figure 1. IR spectra of $\mathrm{CO}$ adsorption $\left(-173^{\circ} \mathrm{C}\right.$ and $133 \mathrm{~Pa} \mathrm{CO}$ at equilibrium) on $\mathrm{CoMo}(\mathrm{CA} / \mathrm{M}=0) / \mathrm{Al}_{2} \mathrm{O}_{3}$ and $\mathrm{CoMo}(\mathrm{CA} / \mathrm{M}=2) / \mathrm{Al}_{2} \mathrm{O}_{3}$ catalysts sulfided with $10 \%(\mathrm{v} / \mathrm{v})$ $\mathrm{H}_{2} \mathrm{~S} / \mathrm{H}_{2}$ at atmospheric pressure and $350{ }^{\circ} \mathrm{C}$ for $2 \mathrm{~h}$.

It was observed that the $\mathrm{CO}$ adsorption bands at $2072 \mathrm{~cm}^{-1}$ and $2060 \mathrm{~cm}^{-1}$ increase with the addition of citric acid, demonstrating that citric acid favors strongly the formation of CoMoS sites. This effect on promoted edge site concentration has previously been reported with other chelating agents such as ethylene diaminotetraacetic acid (EDTA) [26] and nitrilo triacetic acid (NTA) $[27,28]$. 


\subsection{Length and stacking degree determined by HRTEM analysis}

A careful process of measuring the length of the slabs present in each sample was carried out by modifying the contrast to make sure to see the smallest particles. The addition of citric acid leads to a decrease of the average slab length from $2.90 \pm 0.12$ $\mathrm{nm}$ to $1.95 \pm 0.10 \mathrm{~nm}$. The length distribution is given in Figure 2 .
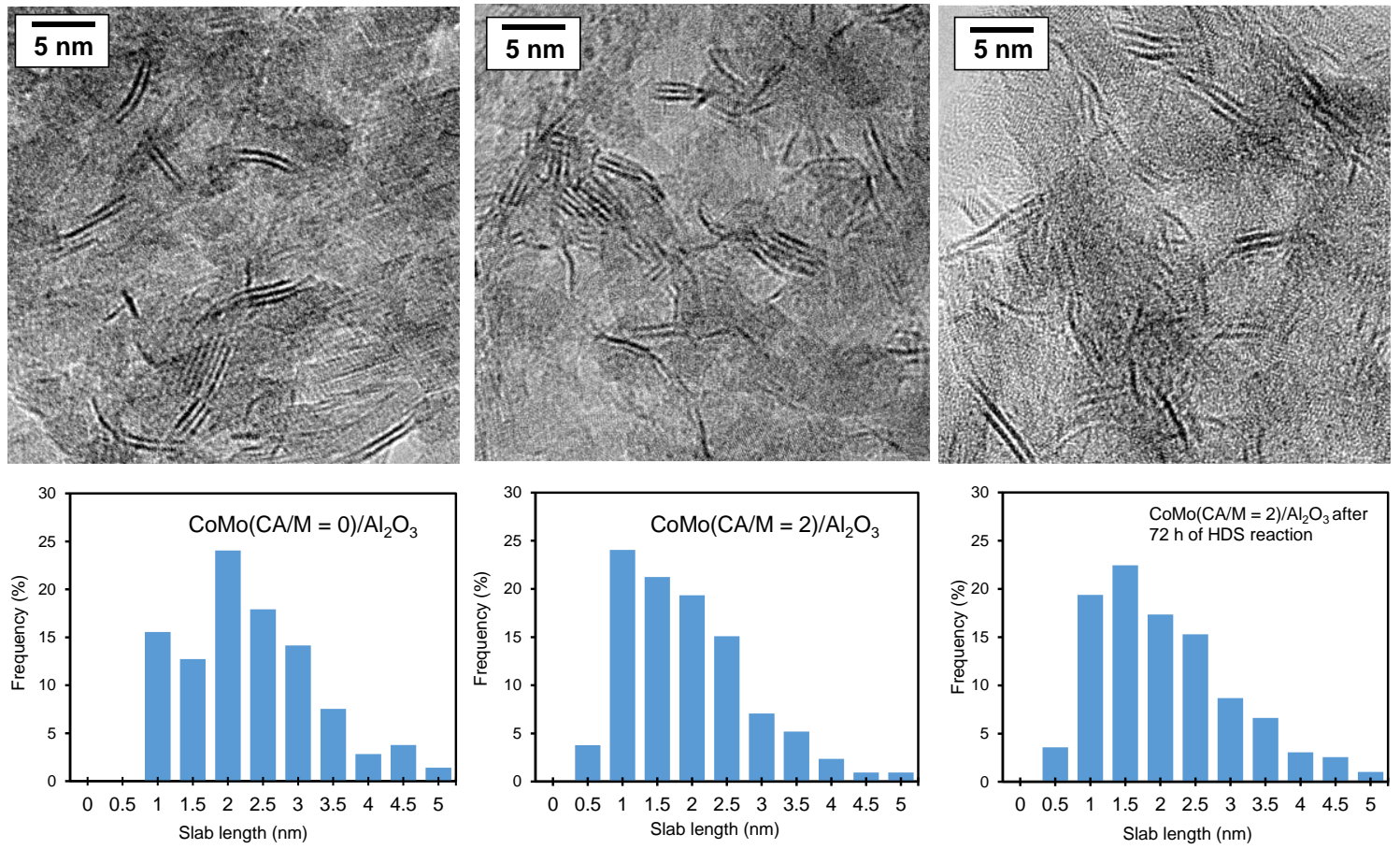

Figure 2. HR-TEM analysis of slab length distribution: images of $\mathrm{CoMo}(\mathrm{CA} / \mathrm{M}=0) / \mathrm{Al}_{2} \mathrm{O}_{3}$, $\mathrm{CoMo}(\mathrm{CA} / \mathrm{M}=2) / \mathrm{Al}_{2} \mathrm{O}_{3}$ and $\mathrm{CoMo}(\mathrm{CA} / \mathrm{M}=2) / \mathrm{Al}_{2} \mathrm{O}_{3}$ after $72 \mathrm{~h}$ of thiophene reaction.

Also an increase of the average stacking number ( $1.80 \pm 0.04$ to $2.20 \pm 0.05)$ is noticed. The presence of particles stacked in two or more slabs is significant in both samples, but the amount of the rather small monolayer slabs observed in the $\mathrm{CoMo}(\mathrm{CA} / \mathrm{M}=2) / \mathrm{Al}_{2} \mathrm{O}_{3}$ sample was much higher than in the $\mathrm{CoMo}(\mathrm{CA} / \mathrm{M}=0) / \mathrm{Al}_{2} \mathrm{O}_{3}$ sample. Such results are in accordance with previously reported results on Mo 
catalysts and ascribed to the reduced interaction between the (Co)MoS slabs and the support due to the addition of citric acid [17].

3.3 Effect of citric acid addition in the $2 D$-morphology of $\mathrm{CoMo}(C A / M=x) / \mathrm{Al}_{2} \mathrm{O}_{3}$

Figure 3 presents the HR STEM-HAADF micrographs of sulfided $\mathrm{CoMo}(\mathrm{CA} / \mathrm{M}=0) / \mathrm{Al}_{2} \mathrm{O}_{3}$ (Figure $3 \mathrm{~A}-\mathrm{C}$ ) and $\mathrm{CoMo}(\mathrm{CA} / \mathrm{M}=2) / \mathrm{Al}_{2} \mathrm{O}_{3}$ (Figure 3D-F) respectively. As expected for the HAADF mode, the observed particles have a good quality contrast and, therefore, the acquisition parameters used are suitable for revealing the $2 \mathrm{D}$ morphology of the slabs in these industrial grade catalysts. On a large field of view, sample $\mathrm{CoMo}(\mathrm{CA} / \mathrm{M}=0) / \mathrm{Al}_{2} \mathrm{O}_{3}$ consist of CoMoS slabs that are distributed over the alumina support in the form of plates. Higher contrast in some zones of both set of images are attributed to an increase of metal density. This is observed more in sample $\mathrm{CoMo}(\mathrm{CA} / \mathrm{M}=0) / \mathrm{Al}_{2} \mathrm{O}_{3}$ and is related to agglomerated or stacked slabs. On the other hand, striking changes are observed for the sample that was prepared in presence of citric acid. The particles observed in the $\mathrm{CoMo}(\mathrm{CA} / \mathrm{M}=2) / \mathrm{Al}_{2} \mathrm{O}_{3}$ sample are characterized by their considerable small size compared to the ones observed in $\mathrm{CoMo}(\mathrm{CA} / \mathrm{M}=0) / \mathrm{Al}_{2} \mathrm{O}_{3}$, and in many occasions, what resembles groups of a few atoms and even individual atoms dispersed all over the support are observed. Such groups and individual atoms were also visible in the images of sulfided CoMo $(\mathrm{CA} / \mathrm{M}=0) / \mathrm{Al}_{2} \mathrm{O}_{3}$ sample but in much lesser extent. The zoom-in in figure (3-E), puts in evidence a particle with dispersion of 1 , this is, all the atoms of the slab are exposed. Their interatomic distances, that are of the order of $3.1 \AA$, are in good agreement with the ones expected for Mo-Mo interatomic distances of $\mathrm{MoS}_{2}$ disulfide $[9,29]$. Recently, we reported a similar observation for 
non-promoted $\mathrm{MoS}_{2}$ prepared as well with and without citric acid as a chelating agent [20]. 


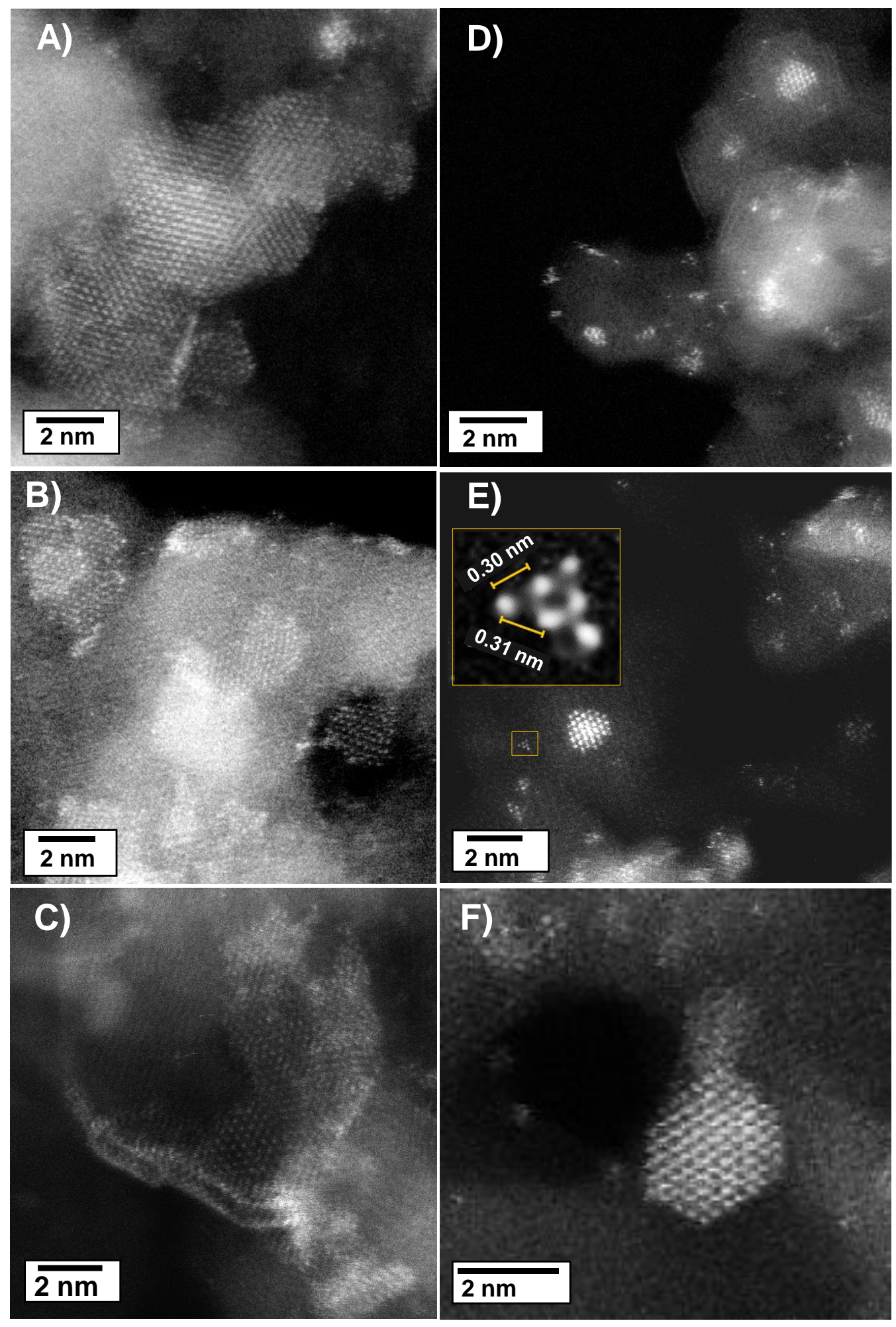

Figure 3. HR STEM-HAADF micrographs of CoMoS particles of $\mathrm{CoMo}(\mathrm{CA} / \mathrm{M}=0) / \mathrm{Al}_{2} \mathrm{O}_{3}(\mathrm{~A}-$ C) and $\mathrm{CoMo}(\mathrm{CA} / \mathrm{M}=2) / \mathrm{Al}_{2} \mathrm{O}_{3}(\mathrm{D}-\mathrm{F})$ of different areas. Inset $\mathrm{E}$ : zoom in of particle with dispersion degree of 1.0 . 
To better understand the improvement of the dispersion degree, measurements of the length and perimeter were carried out in each one of the samples, and using the

Eq. 1, it was found that the addition of citric acid decreases the average length from $2.60 \pm 0.50$ to $1.32 \pm 0.50 \mathrm{~nm}$. The calculated particle dispersion (D) value passes from $48 \%$ for CoMo $(\mathrm{CA} / \mathrm{M}=0) / \mathrm{Al}_{2} \mathrm{O}_{3}$ to $78 \%$ for CoMo $(\mathrm{CA} / \mathrm{M}=2) / \mathrm{Al}_{2} \mathrm{O}_{3}$. Table 1 gathers together the measured and calculated parameters for each of the analyzed samples. Since the catalytic HDS reaction activity is ascribed to the coordinatively unsaturated sites (CUS) of the slabs, located in the edges of the slab, an increase of dispersion is therefore associated to an increase in activity.

\subsection{Observation of $\mathrm{CoMo} / \mathrm{Al}_{2} \mathrm{O}_{3}$ used catalyst.}

Very often TMS catalysts are analyzed after the sulfidation stage, nevertheless, the fact that during the catalytic reaction stage the catalyst is contacted with hydrogen and also with $\mathrm{H}_{2} \mathrm{~S}$ is sometimes overlooked. One question that arises is the stability of the very small agglomerates observed in particular in the sulfided CoMo $(\mathrm{CA} / \mathrm{M}=2) / \mathrm{Al}_{2} \mathrm{O}_{3}$ catalyst. If we take into account that during the catalytic reaction the catalyst is in contact with $\mathrm{H}_{2}$ and with $\mathrm{H}_{2} \mathrm{~S}$ present as a byproduct, could there be a subsequent transformation or reorganization of such agglomerates? To answer this, the sulfided CoMo $(\mathrm{CA} / \mathrm{M}=2) / \mathrm{Al}_{2} \mathrm{O}_{3}$ sample was analyzed after being subjected for 72 hours of catalytic test in order to know if the nanoslabs undergo any alteration. Therefore, this analysis is a way to observe their stability against prolonged reaction conditions. The sulfided CoMo $(\mathrm{CA} / \mathrm{M}=2) / \mathrm{Al}_{2} \mathrm{O}_{3}$ was chosen as used sample since it 
shows more clusters or individual atoms than the sulfided CoMo $(\mathrm{CA} / \mathrm{M}=0) / \mathrm{Al}_{2} \mathrm{O}_{3}$ sample.
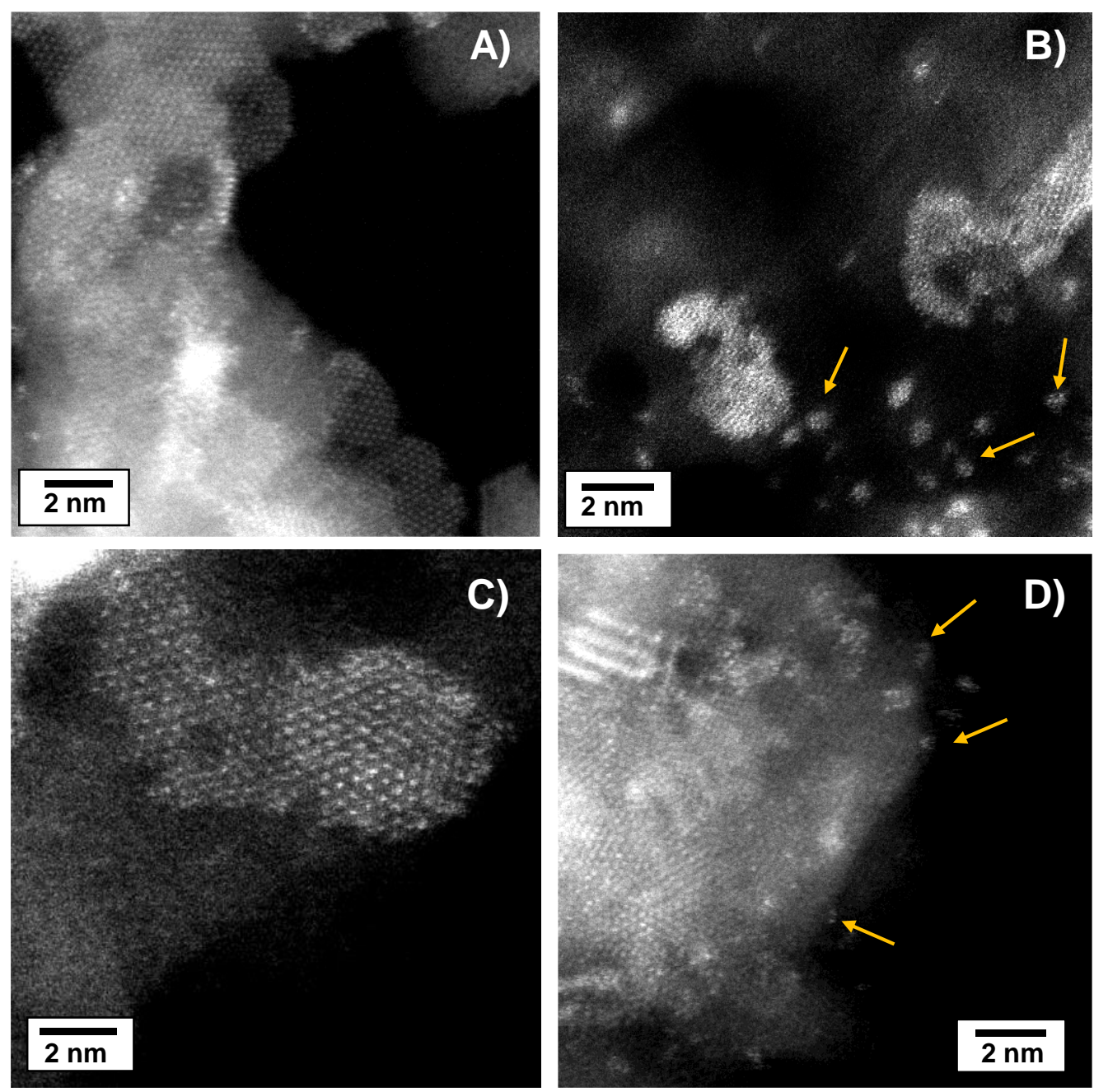

Figure 4. $\mathrm{HR}$ STEM-HAADF micrographs of CoMoS particles of $\mathrm{CoMo}(\mathrm{CA} / \mathrm{M}=2) / \mathrm{Al}_{2} \mathrm{O}_{3}$ after $72 \mathrm{~h}$ of thiophene HDS reaction at $623 \mathrm{~K}$. The arrows indicate that the few atoms agglomerates observed in $\mathrm{CoMo}(\mathrm{CA} / \mathrm{M}=2) / \mathrm{Al}_{2} \mathrm{O}_{3}$ after sulfidation are still present.

The STEM-HAADF images of Figure 4(A-D) revealed that no radical change in the shape of the slabs occurs upon HDS reaction. The agglomerates of a few atoms previously observed in the sulfided $\mathrm{CoMo}(\mathrm{CA} / \mathrm{M}=2) / \mathrm{Al}_{2} \mathrm{O}_{3}$ catalyst remain Figure 
4(B and D). These results suggest that the subnanometric particles have a good stability under reaction conditions.

Figure 5 allows the comparison of the three sulfided promoted samples, $\mathrm{CoMo}(\mathrm{CA} / \mathrm{M}=0) / \mathrm{Al}_{2} \mathrm{O}_{3}, \mathrm{CoMo}(\mathrm{CA} / \mathrm{M}=2) / \mathrm{Al}_{2} \mathrm{O}_{3}$ and used $\mathrm{CoMo}(\mathrm{CA} / \mathrm{M}=2) / \mathrm{Al}_{2} \mathrm{O}_{3}$ after thiophene HDS reaction, in terms of length distribution and processed STEMHAADF images. Complementary, Table I give the values of average length and stacking obtained by TEM for the three samples and the average length and dispersion obtained by STEM-HAADF. Comparison between these values confirm the stability of the $\mathrm{CoMo}(\mathrm{CA} / \mathrm{M}=2)$ catalyst under reaction conditions.

Table I. Parameters calculated from the HR TEM and HR STEM-HAADF images for the ${ }-\mathrm{Al}_{2} \mathrm{O}_{3}$ supported Catalyst.

\begin{tabular}{|c|c|c|c|c|}
\hline Mode & Parameters & $\mathrm{CoMo}(\mathrm{CA} / \mathrm{M}=0)$ & $\mathrm{CoMo}(\mathrm{CA} / \mathrm{M}=2)$ & $\begin{array}{c}\mathrm{CoMo}(\mathrm{CA} / \mathrm{M}=2) \\
\text { after } 72 \mathrm{~h} \text { HDS } \\
\text { reaction }\end{array}$ \\
\hline \multirow{2}{*}{ TEM } & Average length (nm) & $2.90 \pm 0.12$ & $1.95 \pm 0.10$ & $1.94 \pm 0.12$ \\
\hline & Stacking & $1.80 \pm 0.04$ & $2.20 \pm 0.05$ & $2.26 \pm 0.05$ \\
\hline \multirow[t]{4}{*}{ HAADF } & Average length (nm) & $2.60 \pm 0.50$ & $1.32 \pm 0.50$ & $1.36 \pm 0.50$ \\
\hline & $\begin{array}{l}\text { Dispersion } \\
\text { (measured) }\end{array}$ & $0.48 \pm 0.08$ & $0.78 \pm 0.08$ & $0.76 \pm 0.08$ \\
\hline & $\begin{array}{c}{ }^{*} \text { Theoretical } \\
\text { Dispersion (triangle) }\end{array}$ & 0.58 & 0.86 & 0.8 \\
\hline & $\begin{array}{l}{ }^{*} \text { Theoretical } \\
\text { Dispersion (hexagon) }\end{array}$ & 0.43 & 0.7 & 0.63 \\
\hline
\end{tabular}

${ }^{*}$ Calculated from the model Kasztelan for triangular and hexagonal slabs [30]. 

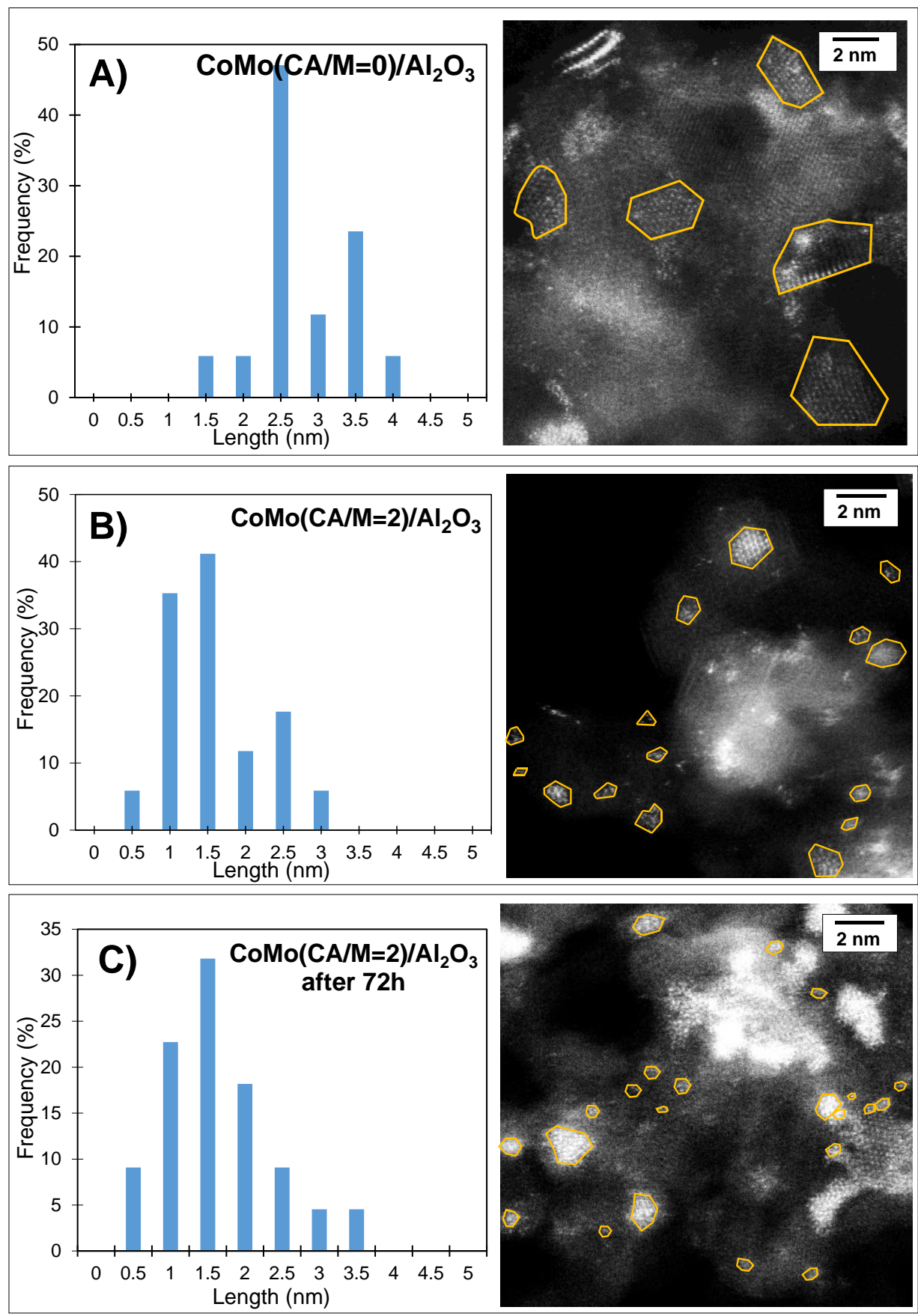

Figure 5. Distribution of the measured length and STEM-HAADF images of the particles of $\mathrm{CoMo}(\mathrm{CA} / \mathrm{M}=0) / \mathrm{Al}_{2} \mathrm{O}_{3}, \mathrm{CoMo}(\mathrm{CA} / \mathrm{M}=2) / \mathrm{Al}_{2} \mathrm{O}_{3}$ and $\mathrm{CoMo}(\mathrm{CA} / \mathrm{M}=2) / \mathrm{Al}_{2} \mathrm{O}_{3}$ after thiophene HDS reaction (72h). 
For the three samples, the mean length value obtained from the HR STEM-HAADF images is lower than the one obtained from the HRTEM ones, underlying that it can be hard to distinguish the smallest particles in HRTEM. Moreover, the length distribution from both techniques also differ: more homogeneous lengths are observed in HR STEM-HAADF than in HRTEM. Similar results were previously reported in [20]. Note that the point to point resolution for STEM-HAADF technique $(0.78 \AA)$ is also better than that for HRTEM (1.0 $)$.

The dispersion value obtained from the STEM-HAADF slab images is closer to the theoretical dispersion obtained with hexagonal shape in absence of citric acid while with citric acid it tends to be closer to the theoretical dispersion calculated for triangular slabs. Compared to the $\mathrm{Mo} / \mathrm{Al}_{2} \mathrm{O}_{3}$ sample, it seems that the effect of citric acid on the slab shape occurs in the opposite direction. Nevertheless, this result could also indicate that these triangular particles are exposing S-edges, i. e. that citric acid still favors S-edge exposition. Future work along with spectroscopy is presently being carried out in order to understand better and confirm this hypothesis.

\section{Conclusion}

HR STEM-HAADF unequivocally demonstrates that adding citric acid in the preparation of CoMo catalysts significantly reduces the size of CoMoS nano-slabs. This result goes hand in hand with the infrared spectra results observed, where the band associated with the active CoMoS sites increases considerably. Numerous agglomerates formed by a few atoms with a high degree of dispersion are detected in the sulfide sample $\mathrm{CoMo}(\mathrm{CA} / \mathrm{M}=2) / \mathrm{Al}_{2} \mathrm{O}_{3}$. These clusters are proved to be stable 
after being subjected to a thiophene HDS reaction for 72 hours in the same way as the nanometric ones. This demonstrates that the catalysts retain their integrity during the catalytic reaction process and therefore that analyzing the catalyst after sulfidation is relevant to understand the catalyst under HDS operational conditions. Next step is to study the variation of atomic contrast in several slabs of CoMo catalysts in order to verify the decoration model as it has been reported recently for NiW catalysts.

\section{Acknowledgements}

L. Zavala-Sanchez acknowledges the Mexican National Council for Science and Technology (CONACYT) for the Ph. D. grant. The authors acknowledge LABEX EMC3 for the financial support to MIMOSA project.

\section{References}

[1] Sulfur production report by the United States Geological Survey, No Title, Minerals.Usgs.Gov. (2017).

[2] EIA, Annual Energy Outlook 2019 with projections to 2050, USA, 2019. www.eia.gov/aeo.

[3] T. Alphazan, A. Bonduelle-Skrzypczak, L. Legens, A.-S. Gay, Z. Boudene, M. Girleanu, O. Ersen, C. Cope, P. Raybaud, Highly Active Nonpromoted Hydrotreating Catalysts through the Controlled Growth of a Supported Hexagonal WS2 Phase, ACS Catal. 4 (2014) 42. doi:10.1021/cs501311m.

[4] H. Topsøe, B.S.. Clausen, F.E.. Massoth, Catalysis Science and Technology, Springer, Berlin, 1996. doi:10.1007/978-3-642-61040-0_1.

[5] S. Topsøe, H., Clausen, B. S., Candia, R., Wivel, C., \& Mørup, In Situ Mössbauer Emission Spectroscopy Studies of Unsupported and Supported Sulfided Co-Mo Hydrodesulfurization Catalysts: Evidence for and Nature of a Co-Mo-S Phase, J. 
Catal. 68 (1981) 433-452. doi:10.1016/0021-9517(81)90114-7.

[6] F. Besenbacher, M. Brorson, B.S. Clausen, S. Helveg, B. Hinnemann, J. Kibsgaard, J. V. Lauritsen, P.G. Moses, J.K. Nørskov, H. Topsøe, Recent STM, DFT and HAADF-STEM studies of sulfide-based hydrotreating catalysts: Insight into mechanistic, structural and particle size effects, Catal. Today. 130 (2008) 86-96. doi:10.1016/j.cattod.2007.08.009.

[7] H. Topsøe, B.S. Clausen, Importance of Co-Mo- S Type Structures in Hydrodesulfurization, Catal. Rev. Sci. Eng. $26 \quad$ (1984) 395-420. doi:10.1080/01614948408064719.

[8] L.S. Byskov, J.K. Nørskov, B.S. Clausen, H. Topsøe, Edge termination of MoS2 and CoMoS catalyst particles, Catal. Letters. $64 \quad$ (2000) 95-99. doi:10.1023/A:1019063709813.

[9] B. Baubet, M. Girleanu, A.S. Gay, A.L. Taleb, M. Moreaud, F. Wahl, V. Delattre, E. Devers, A. Hugon, O. Ersen, P. Afanasiev, P. Raybaud, Quantitative TwoDimensional (2D) Morphology-Selectivity Relationship of CoMoS Nanolayers: A Combined High-Resolution High-Angle Annular Dark Field Scanning Transmission Electron Microscopy (HR HAADF-STEM) and Density Functional Theory (DFT) Study, ACS Catal. 6 (2016) 1081-1092. doi:10.1021/acscatal.5b02628.

[10] E. Krebs, B. Silvi, P. Raybaud, Mixed sites and promoter segregation: A DFT study of the manifestation of Le Chatelier's principle for the $\mathrm{Co}(\mathrm{Ni}) \mathrm{MoS}$ active phase in reaction conditions, Catal. Today. (2008) 160-169. doi:10.1016/j.cattod.2007.06.081.

[11] J. Chen, F. Maugé, J. El Fallah, L. Oliviero, IR spectroscopy evidence of MoS2 morphology change by citric acid addition on MoS2/Al2O3 catalysts - A step forward to differentiate the reactivity of M-edge and S-edge, J. Catal. 320 (2014) 170-179. doi:10.1016/j.jcat.2014.10.005.

[12] J. Chen, L. Oliviero, X. Portier, F. Maugé, On the morphology of MoS 2 slabs on MoS ${ }_{2} / \mathrm{Al}_{2} \mathrm{O}_{3}$ catalysts: the influence of Mo loading, RSC Adv. 5 (2015) 81038-81044. doi:10.1039/C5RA14768A.

[13] A. Travert, C. Dujardin, F. Maugé, S. Cristol, J.F. Paul, E. Payen, D. Bougeard, Parallel between infrared characterisation and ab initio calculations of $\mathrm{CO}$ adsorption on sulphided Mo catalysts, Catal. Today. 70 (2001) 255-269.

[14] M. Girleanu, S. Lopes Silva, D. Ihiawakrim, A. Chaumonnot, A. BonduelleSkrzypczak, F. Lefebvre, V. Dufaud, A.S. Gay, O. Ersen, HAADF-STEM highresolution study of nanometric MoS2 inside mesoporous SBA-15, Microporous 
Mesoporous Mater. 217 (2015) 190-195. doi:10.1016/j.micromeso.2015.06.021.

[15] S.J. Nellist, P. D., \& Pennycook, Direct Imaging of the Atomic Configuration of Ultradispersed Catalysts, Science (80-. ). 274 (1996) 413-415. doi: 10.1126/science.274.5286.413\%0AArticle.

[16] K. Al-Dalama, A. Stanislaus, A Comparative Study of the Influence of Chelating Agents on the Hydrodesulfurization (HDS) Activity of Alumina and Silica-AluminaSupported CoMo Catalysts, Energy and Fuels. 20 (2006) 1777-1783. doi:10.1021/ef060125a.

[17] R. Cattaneo, T. Shido, R. Prins, The Relationship between the Structure of NiMo/SiO2 Catalyst Precursors Prepared in the Presence of Chelating Ligands and the Hydrodesulfurization Activity of the Final Sulfided Catalysts, J. Catal. 185 (1999) 199_ 212. doi:10.1006/JCAT.1999.2492.

[18] S. Badoga, K.C. Mouli, K.K. Soni, A.K. Dalai, J. Adjaye, Beneficial influence of EDTA on the structure and catalytic properties of sulfided NiMo/SBA-15 catalysts for hydrotreating of light gas oil, Appl. Catal. B Environ. 125 (2012) 67-84. doi:10.1016/j.apcatb.2012.05.015.

[19] J. Chen, J. Mi, K. Li, X. Wang, E. Dominguez Garcia, Y. Cao, L. Jiang, L. Oliviero, F. Oise, Role of Citric Acid in Preparing Highly Active CoMo/Al 2 O 3 Catalyst: From Aqueous Impregnation Solution to Active Site Formation, Ind. Eng. Chem. Res. 56 (2017) 14172-14181. doi:10.1021/acs.iecr.7b02877.

[20] L. Zavala-Sanchez, X. Portier, F. Maugé, L. Oliviero, High-resolution STEM-HAADF microscopy on a $y-\mathrm{Al} 2 \mathrm{O} 3$ supported MoS2 catalyst-proof of the changes in dispersion and morphology of the slabs with the addition of citric acid, Nanotechnology. 31 (2019) 035706. doi:10.1088/1361-6528/ab483c.

[21] E. Dominguez Garcia, J. Chen, E. Oliviero, L. Oliviero, F. Maugé, New insight into the support effect on HDS catalysts: evidence for the role of Mo-support interaction on the MoS 2 slab morphology, Appl. Catal. B Environ. (2020) 117975. doi:10.1016/j.apcatb.2019.117975.

[22] J. Chen, L. Oliviero, X. Portier, F. Mau, On the morphology of MoS 2 slabs on MoS 2 /AI 2 O 3 catalysts: the influence of Mo loading, RSC. 5 (2015) 81038-81044. doi:10.1039/c5ra14768a.

[23] A. Travert, C. Dujardin, F. Maugé, E. Veilly, S. Cristol, J.-F. Paul, E. Payen, CO Adsorption on CoMo and NiMo Sulfide Catalysts: A Combined IR and DFT Study, Phys. Chem. B. 110 (2006) 1261-1270. doi:10.1021/jp0536549. 
[24] F. Maugé, J.C. Lavalley, FT-IR Study of CO Adsorption on Sulfided Mo/Al2O3 Unpromoted or Promoted by Metal Carbonyls: Titration of Sites, J. Catal. 137 (1992) 69-76. doi:10.1016/0021-9517(92)90139-9.

[25] E.D. Garcia, Effet du support sur la morphologie et l'activité des catalyseurs d'hydrodésulfuration, Université de Caen, 2017.

[26] M.A. Lélias, E. Le Guludec, L. Mariey, J. Van Gestel, A. Travert, L. Oliviero, F. Maugé, Effect of EDTA addition on the structure and activity of the active phase of cobaltmolybdenum sulfide hydrotreatment catalysts, Catal. Today. 150 (2010) 179-185. doi:10.1016/j.cattod.2009.07.107.

[27] M.A. Lélias, J. van Gestel, F. Maugé, J.A.R. van Veen, Effect of NTA addition on the formation, structure and activity of the active phase of cobalt-molybdenum sulfide hydrotreating catalysts, Catal. Today. $130 \quad$ (2008) 109-116. doi:10.1016/J.CATTOD.2007.07.018.

[28] M.A. Lélias, P.J. Kooyman, L. Mariey, L. Oliviero, A. Travert, J. Van Gestel, J.A.R. Van Veen, F. Maugé, Effect of NTA addition on the structure and activity of the active phase of cobalt-molybdenum sulfide hydrotreating catalysts, (2009). doi:10.1016/j.jcat.2009.07.006.

[29] F.L. Deepak, R. Esparza, B. Borges, X. Lopez-Lozano, M. Jose-Yacaman, Direct Imaging and Identification of Individual Dopant Atoms in MoS2 and WS2 Catalysts by Aberration Corrected Scanning Transmission Electron Microscopy, ACS Catal. 1 (2011) 537-543. doi:10.1021/cs100141p.

[30] S. Kasztelan, J. Grimblot, J.P. Bonnelle, E. Payew, H. Toulhoat, Y. Jacquin+, Preparation of Co-Mo-yAl2O3 and Ni-Mo-yAl2O3 catalysts by $\mathrm{pH}$ regulation of molybdenum solution. characterization of supported species and hydrogenation activities, Appl. Catal. 7 (1983) 91-112. doi:0.1016/0166-9834(83)80241-3.

[31] M. Nikulshina, A. Mozhaev, C. Lancelot, M. Marinova, P. Blanchard, E. Payen, C. Lamonier, P. Nikulshin, MoW synergetic effect supported by HAADF for alumina based catalysts prepared from mixed SiMonW12-n heteropolyacids, Appl. Catal. B Environ. 224 (2018) 951-959. doi:10.1016/j.apcatb.2017.11.049. 